\title{
PENGARUH KONDISI JALUR PEDESTRIAN DAN STREET FURNITURE DI JALAN MALIOBORO TERHADAP KENYAMANAN RUANG PUBLIK
}

\author{
Muhammad Nashif Saifuddin \\ Program Studi Arsitektur Fakultas \\ Teknik Universitas Muhammadiyah \\ Surakarta \\ shif.nashif@gmail.com

\section{Qomarun} \\ Program Studi Arsitektur Fakultas \\ Teknik Universitas Muhammadiyah \\ Surakarta \\ qomarun@ums.ac.id
}

\begin{abstract}
ABSTRAK
Kawasan Malioboro merupakan salah satu ikon kota Yogyakarta. Malioboro menjadi salah satu destinasi favorit untuk berwisata di kota tersebut. Kawasan ini merupakan pertokoan yang melintang di sepanjang jalan Malioboro. Hampir setiap tahunnya selalu ramai dikunjungi oleh wisatawan, baik wisatawan dalam negeri maupun luar negeri. Hal ini membuat jalan Malioboro menjadi zona yang sangat padat. Jalur pedestrian dan street furniture menjadi sangat vital bagi kenyamanan dalam beraktivitas di ruang publik. Penelitian ini bertujuan untuk mengetahui pengaruh kondisi dan street furniture dengan tingkat kenyamanan ruang publik yang dirasakan oleh pengguna. Metode yang digunakan adalah metode kualitatif dan kuantitatif, dengan cara melakukan observasi fisik lalu memvalidasi hasil temuan observasi fisik dengan pendapat dari pengguna yang diperoleh dari hasil penyebaran 90 kuisioner tentang kondisi dari jalur pedestrian dan street furniture yang berpengaruh terhadap kenyamanan ruang publik. Hasil penelitian menyimpulkan dari 90 sampel responden pengguna jalan menyatakan bahwa kondisi jalur pedestrian dan street furniture memperoleh predikat baik dengan skor 2,59 (skala 4). Skor terendah dari sisi kelancaran jalur pedestrian dan skor tertinggi dari aspek estetika. Hasil final menunjukkan bahwa 81 \% responden menyatakan bahwa Jalan Malioboro telah memenuhi kenyamanan ruang publik, baik kondisi jalur pedestrian maupun street furniture.
\end{abstract}

KATA KUNCI: jalur pedestrian, Malioboro, kenyamanan, ruang publik, street furniture

\section{PENDAHULUAN}

Malioboro merupakan salah satu destinasi wisata yang bertempat di Daerah Istimewa Yogyakarta (DIY). Setiap tahunnya tempat tersebut dapat menarik ratusan bahkan ribuan orang untuk mengunjunginya. Lokasi Jalan Malioboro ini selalu menjadi pusat perhatian khalayak umum jika berkunjung di Yogyakarta. Bukan hanya itu saja, kota yang kental akan pendidikan serta budayanya tersebut menjadi magnet penarik wisatawan yang berkunjung ke kota Yogyakarta.

Hal yang terlihat menarik dan unik dari kawasan ini adalah pedestrian yang lebar dan street furniture yang membentang sepanjang kawasan pertokoan Jalan Malioboro. Di sepanjang jalan tersebut terdapat berbagai aktivitas kebudayaan dan juga ekonomi sosial, dengan tenda tenda yang menyajikan makanan serta street furniture yang menunjang kenyamanan berinteraksi, beristirahat dan berjalan kaki.

Ruang publik memberikan akses untuk pengguna dalam kegiatan di suatu kawasan Oleh karena itu perlu perhatian khusus dalam penyediaan ruang publik, terutama di Jalan Malioboro yang merupakan jalan protokol dan terdapat pedestrian yang mendukung untuk aktivitas publik. Aktivitas ini mewadahi bagi para pengguna terutama oleh komunitas atau perseorangan yang berada di Jalan Malioboro. Ketersediaan street furniture dan area pedestrian yang luas sering kali menjadi faktor utama dalam kenyamanan pengguna jalan. Ketersediaan pedestrian dan street furniture yang tidak sesuai dengan kondisi sekitar dan perilaku pengguna akan menimbulkan penolakan, sehingga menyebabkan pemakai tidak tertarik untuk mempergunakannya. Oleh sebab itu perlu dilakukan kajian mengenai korelasi antara kondisi pedestrian dan street furniture dengan kenyaman ruang publik yang terbentuk.

Penelitian ini bertujuan untuk mengetahui tingkat kegunaan atau pengaruh pedestrian dan keberadaan street furniture dengan kenyamanan ruang public melalui skala penilaian, sehingga kita dapat mengetahui bagaimana standar dan parameter yang diinginkan pengguna. Dengan demikian dapat diketahui tingkat kenyamanan ruang publik yang dirasakan oleh pengguna.

Ruang publik adalah tempat dimana semua orang menggunakan dan mempunyai hak yang sama. Ruang publik juga merupakan ruang umum atau tempat yang digunakan secara umum untuk 
mewadahi kegiatan atau aktivitas khalayak. Ruang publik juga bisa berfungsi sebagai ruang pendukung untuk kegiatan semua makhluk yang ada di bumi.

Dalam pernyataan Project for Public Spaces ruang publik adalah suatu ruang yang digunakan untuk kegiatan bersama yang merupakan wadah dari aktivitas atau kegiatan umum untuk masyarakat. Ruang terbuka juga merupakan ruang yang dapat membentuk suatu komunitas-komunitas masyarakat yang saling berinteraksi dan mengintegerasi antar sesama. Ruang terbuka juga merupakan elemen penting yang membentuk suatu kota. Sebagai contohnya taman, plaza, halte, pedestrian, lapangan dan lain-lain, yang dapat membuat masyarakat lebih aktif dan saling berinteraksi dalam wadah yang nyaman dan layak. Ruang publik juga dapat mengintegersikan antar blok-blok maupun bangunan dalam ruang tertentu.

Iswanto (2006) menyebutkan bahwa pedestrian diartikan sebagai pergerakan atau sirkulasi perpindahan manusia/ pengguna dari satu tempat asal menuju ke tempat yang ditujunya dengan cara berjalan kaki. Setiap ruas penghubung atau jalan perlu dilengkapi dengan adanya suatu area yang difungsikan khusus area manusia untuk berjalan kaki tanpa adanya suatu hambatan yang besar. Di perkotaan setiap ruas jalan harus dilengkapi dengan jalur pedestrian yang mana membantu manusia dalam bertransportasi dan berpindah tempat. Terlebih lagi di tengah kota yang sekarang ini sudah semakin padat dan minim ruang terbuka yang diperuntukkan untuk manusia melintasi secara langsung. Dalam Planologi UIR (2011) dijelaskan bahwa jalur pedestrian dalam konteks perkotaan biasanya dimaksudkan sebagai ruang khusus untuk pejalan kaki yang berfungsi sebagai sarana pencapaian yang dapat melindungi pejalan kaki dari bahaya yang datang dari kendaraan bermotor. Maulani (2010) menyebutkan bahwa jalur pedestrian tidak hanya digunakan untuk memfasilitasi para pejalan kaki tetapi juga digunakan untuk pengguna sepeda. Antara jalur pejalan kaki dan jalur sepeda dipisahkan oleh jalur hijau.

Rappoport dan Mouden (1987) menjelaskan bahwa semua aktivitas termasuk aktivitas pedestrian mengandung empat hal yaitu : (a) Aktivitas yang sebenarnya yaitu: berjalan, makan, dan lain-lain, (b) Cara melakukan yaitu: berjalan di jalur pedestrian, makan di rumah, dan lain-lain, c) Aktivitas tambahan terkait dalam satu kesatuan sistem aktivitas seperti : berjalan sambil melihat etalase toko (window shopping), (d) Makna dari aktivitas yaitu menghayati lingkungan.

Kegiatan di dalam jalur pedestrian sangat didukung oleh street furniture atau perabot jalan. Harris dan Dines (1988) menyatakan bahwa street furniture atau perabot jalan adalah semua elemen yang ditempatkan secara kolektif pada suatu lansekap jalan untuk kenyamanan, kesenangan, informasi, kontrol sirkulasi, dan perlindungan pengguna jalan. Elemen ini harus merefleksikan karakter dari lingkungan setempat dan menyatu dengan sekitar. Kriteria elemen yang digunakan meliputi: bahan yang mudah didapat, kuat terhadap cuaca, mudah dalam perawatan, mudah dalam perbaikan, kuat dan aman bagi pengguna jalan maupun lingkungan sekitarnnya.

\section{METODE PENELITIAN}

Metode yang digunakan dalam studi ini adalah metode kualitatif dan juga metode kuantitatif. Metode kualitatif berupa data hasil observasi fisik yang diverifikasi dengan metode kuantitatif berupa kuisioner pengguna.

Pengumpulan data adalah bagian dari cara untuk mendapatkan data yang valid untuk penelitian. Pada penelitian kali ini penulis menggunakan 2 kali pengumpulan data yang berupa :

1. Identifikasi dari kondisi fisik Jalur pedestrian dengan pengamatan dan penelitian secara langsung di lokasi, yang berupa foto dan observasi.

2. Melakukan penyebaran kuisioner untuk mengetahui persepsi pejalan kaki. Penyebaran kuisioner dilakukan secara langsung kepada pengguna dari jalur pedestrian di Malioboro. Hasil final dari analisis akan disajikan berupa nilai/angka, dan kemudian didiskripsikan.

Data penyebaran kuisioner ditentukan sebanyak 90 sampel responden yang dibagikan disepanjang jalan Malioboro. Analisis data yang digunakan dalam mencapai tujuan studi adalah sebagai berikut :

1. Analisis kondisi fisik jalur pedestrian Jalur pedestrian akan diteliti secara deskriptif dengan cara membandingkan kondisi fisik pedestrian saat ini dengan standar kebijakan perundang-undangan pemerintah terkait kriteria dan spesifikasi berupa standar ketentuan dalam melakukan perencanaan, penyediaan, pemanfaatan pada fasilitas pedestrian.

2. Analisis persepsi pejalan kaki terhadap penataan fasilitas pedestrian

Dalam melakukan analisis persepsi pejalan kaki terhadap kinerja fasilitas pedestrian, maka diperoleh variabel berdasarkan teori yang ada terkait dengan indikator tercapainya konsep pengembangan fasilitas jalan yang didalamnya mencakup komponen dan indikator yang berpengaruh pada seberapa baik kinerja dari sebuah fasilitas pedestrian. 
Penarikan kesimpulan terkait kenyaman ruang publik di Jalur Pedestrian Malioboro dinilai dari hasil kuisioner responden yang dihitung dalam bentuk prosentase hasil yang divalidasi dari data hasil observasi pengamatan pertama.

\section{HASIL PENELITIAN}

Data dibagi menjadi 3 segmen di sepanjang jalan Malioboro (gambar 1).

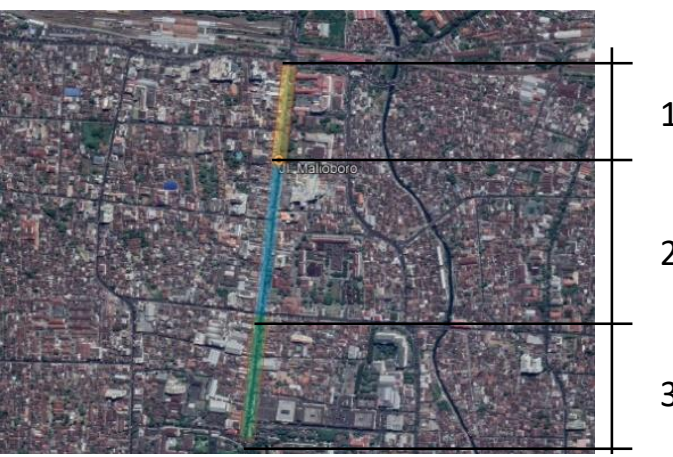

Segmen 1: jalan Malioboro depan Hotel Inna Garuda sampai batas jalan Sosrowijayan

Segmen 2: batas jalan Sosrowijayan sampai batas jalan Pajeksan

Segmen 3: batas jalan Pajeksan sampai perempatan Jalan Ahmad Dahlan

\section{Gambar 1. Peta Segmen Jalan Malioboro}

\section{Segmen 1:}
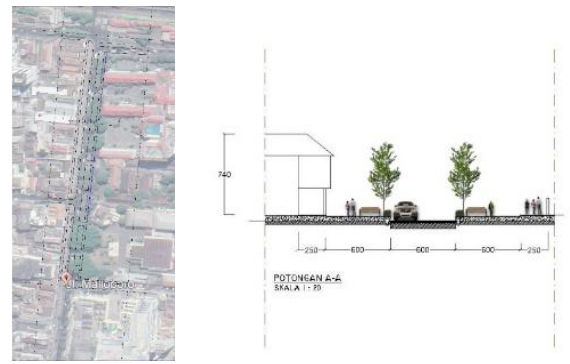

Gambar 2. Potongan Segmen 1 Jalan Malioboro

Pada segmen 1 kondisi jalur pedestrian sebelah barat berbeda dengan pedestrian yang sebelah timur, tidak terdapat selasar pertokoan, karena sisi timur jalan Malioboro merupakan perkantoran.

\section{Segmen 2:}
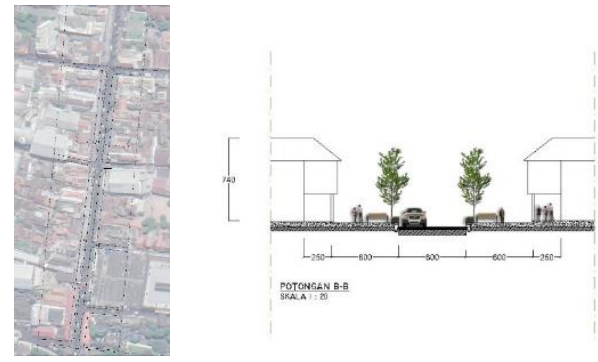

Gambar 3. Potongan Segmen 2 Jalan Malioboro
Pada segmen 2 kondisi jalur pedestrian sama, dan terdapat dikedua sisi jalan, baik sebelah barat dan timur jalan Malioboro.

\section{Segmen 3:}
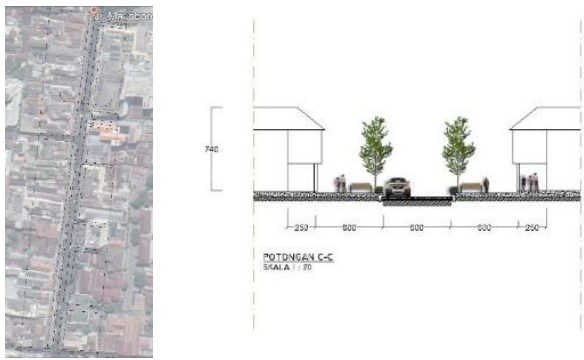

Gambar 4. Potongan Segmen 3 Jalan Malioboro

Pada segmen 3 kondisi jalur pedestrian sama, dan terdapat dikedua sisi jalan, baik sebelah barat dan timur jalan Malioboro.

Berikut adalah hasil dari data observasi langsung yang dilakukan disepanjang Jalan Malioboro :

Tabel 1. Kondisi Street Furniture Jalan Malioboro

\begin{tabular}{|c|c|c|c|}
\hline No & Nama & $\begin{array}{c}\text { Keterse } \\
\text { diaan }\end{array}$ & Foto dan Kondisi/Keterangan \\
\hline 1 & Bangku & $\sqrt{ }$ & $\begin{array}{l}\text { Baik } \\
\text { Kondisi bangku bersih dan } \\
\text { ukuran yang nyaman sesuai } \\
\text { dengan kondisi fisik yang baik }\end{array}$ \\
\hline 2 & $\begin{array}{l}\text { Lampu } \\
\text { Penera } \\
\text { ngan }\end{array}$ & $\sqrt{ }$ & $\begin{array}{l}\text { Baik } \\
\text { Kondisi lampu } \\
\text { penerangan } \\
\text { yang menyala } \\
\text { dengan kondisi } \\
\text { fisik yang } \\
\text { masih bagus }\end{array}$ \\
\hline 3 & Kanopi & $\sqrt{ }$ & $\begin{array}{l}\text { Baik } \\
\text { Kondisi kanopi } \\
\text { cukup luas, } \\
\text { akan } \\
\text { Tetapi kanopi } \\
\text { hanya } \\
\text { teerrsedia } \\
\text { pada segmen } 1\end{array}$ \\
\hline 4 & Halte & $\sqrt{ }$ & $\begin{array}{l}\text { Baik } \\
\text { Kondisi halte yang memadahi } \\
\text { namun kadang kapasitas yang } \\
\text { sering melampaui batas }\end{array}$ \\
\hline
\end{tabular}




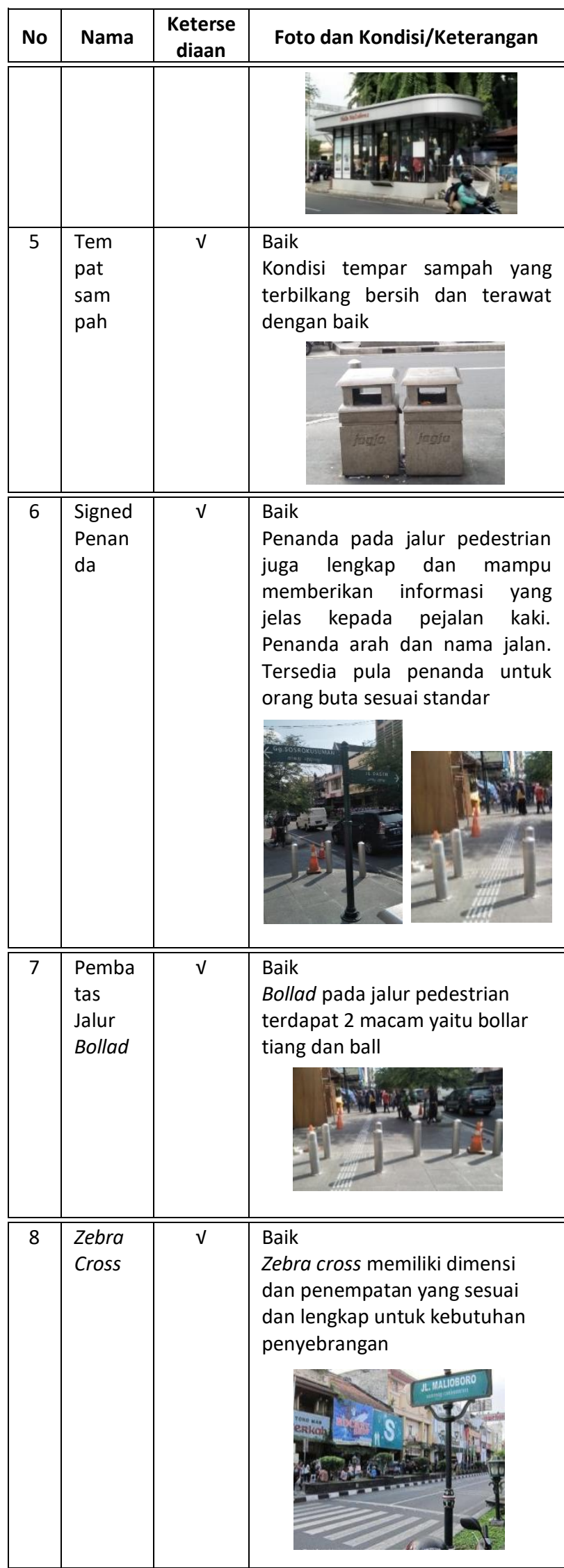

Pengambilan kuisioner dilakukan dengan 90 sampel responden. Pertanyaan kuisioner meliputi pertanyaan tentang penilaian pengguna terhadap kondisi jalur pedestrian dan street furniture di Jalan Malioboro, serta penilaian penggguna mengenai standar kenyamanan ruang publik di Jalan Malioboro.

\section{PEMBAHASAN}

Jalur pedestrian di Jalan Malioboro sudah memenuhi standar dimensi tentang jalur sirkulasi. Selasar pertokoan memiliki lebar 2,5 meter dengan persyaratan sirkulasi dua arah. Bagian trotoar jalan memiliki lebar 6 meter dengan ruang penepatan street furniture sebesar 3,2 meter dan ruang untuk sirkulasi sebesar 2,8 meter dengan persyaratan sirkulasi 2 arah. Kondisi fisik street furniture yang ada di Malioboro berdasarkan data dari observasi penulis, street furniture yang ada memiliki kondisi yang baik dengan kriteria dengan skor 3 ( Baik ).

Data yang didapat dari penyebaran kuisioner dengan perolehan responden 46 orang laki-laki dan 44 orang perempuan. Dari hasil penyebaran kuisioner diperoleh data tentang penggunaan fasilitas publik dan kenyamanan pengguna terhadap PKL seperti gambar 5 .

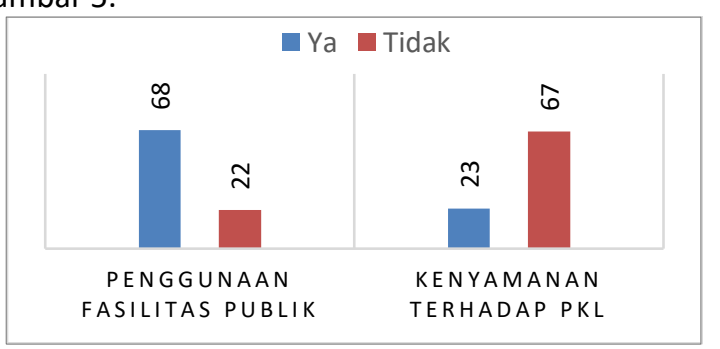

Gambar 5. Hasil data kuisioner mengenai penggunaan fasilitas publik dan kenyamanan terhadap PKL

Data sesuai gambar 5 dapat disimpulkan bahwa dari 90 responden, 68 orang pernah menggunakan fasilitas ruang publik dan 22 orang belum pernah menggunakannya, serta 67 orang merasa tidak terganggu dengan PKL di Jalan Malioboro dan 23 orang merasa terganggu.

Gambar 6 menunjukan pendapat responden terhadap jalur pedestrian dan street furniture.

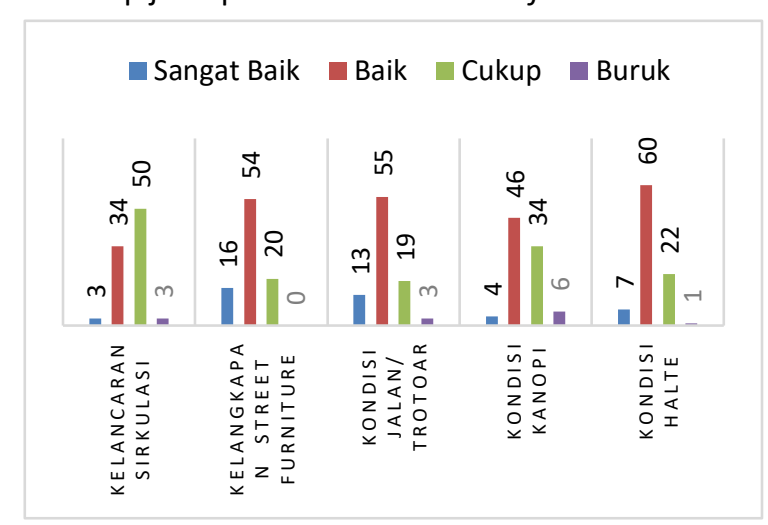




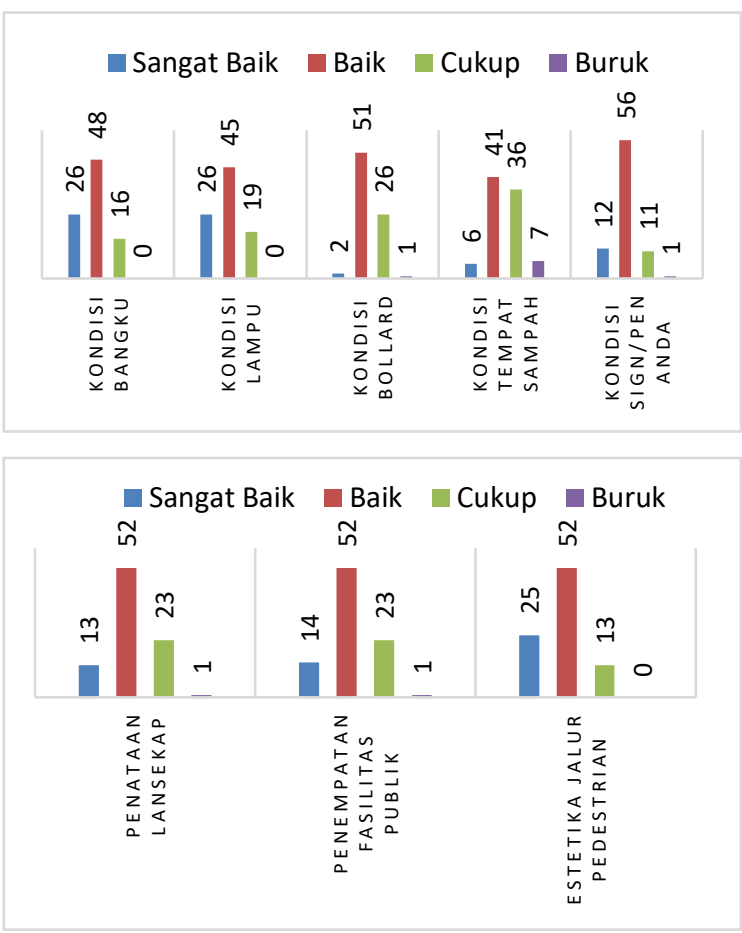

Gambar 6. Hasil data kuisioner mengenai kondisi jalur pedestrian dan street furniture di Malioboro

Data dalam gambar 6 merupakan sampel pengisian kuisioner tentang persepsi pengguna tentang kondisi street Furniture di Jalan Malioboro. Rata-rata persepsi pengguna menyatakan baik, hanya satu poin dengan pernyataan cukup yaitu poin kelancaran sirkulasi jalur pedestrian. Kemudian dari data tersebut diambil data kuisioner tentang pendapat pengguna terhadap kenyamanan ruang publik di Jalan Malioboro.

Berdasarkan standar dan dari hasil observasi maka data akan dikomparasikan dengan persepsi dari pengguna jalur pedestrian di Malioboro dengan kriteria skor penilaian sebagai berikut :
a. Sangat Baik $=4$
b. Baik = 3
c. Cukup = 2
d. Buruk = 1

Dari bebrapa kriteria skor diatas akan dihitung jumlah total skor, kemudian diperoleh nilai rata rata dengan membagi jumlah responden, sehingga nanti akan didapat skor final dari kondisi Jalur Pedestrian dan Street Furniture yang dicocokkan dengan tabel deskripsi angka (tabel 2) :

Tabel 2. Deskripsi Skor Angka Penilaian

\begin{tabular}{cc}
\hline Skor & Deskripsi \\
\hline$(0-1)$ & Buruk \\
\hline$(1-2)$ & Cukup \\
\hline$(2-3)$ & Baik \\
\hline$(3-4)$ & Sangat Baik \\
\hline
\end{tabular}

Berikut adalah penilaian mengenai jalur pedestrian dan street furniture di jalan Malioboro :
Tabel 3. Tabel Penilaian Jalur Pedestrian dan Street Furniture

\begin{tabular}{|c|c|c|c|c|}
\hline No. & Nama & Poin & Jumlah skor & $\begin{array}{c}\text { Nilai Rata- } \\
\text { rata }\end{array}$ \\
\hline \multirow{4}{*}{1} & \multirow{4}{*}{$\begin{array}{l}\text { Kelancaran } \\
\text { Sirkulasi }\end{array}$} & 3 & 12 & 2,41 \\
\hline & & 34 & 102 & (Baik) \\
\hline & & 50 & 100 & \\
\hline & & 3 & 3 & \\
\hline \multirow{4}{*}{2} & \multirow{4}{*}{$\begin{array}{l}\text { Kelengkapan } \\
\text { Street } \\
\text { Furniture }\end{array}$} & 16 & 64 & 2,95 \\
\hline & & 54 & 162 & (Baik) \\
\hline & & 20 & 40 & \\
\hline & & 0 & 0 & \\
\hline \multirow{4}{*}{3} & \multirow{4}{*}{ Kondisi Trotoar } & 13 & 52 & 2,86 \\
\hline & & 55 & 165 & (Baik) \\
\hline & & 19 & 38 & \\
\hline & & 3 & 3 & \\
\hline \multirow{4}{*}{4} & \multirow{4}{*}{ Kondisi Kanopi } & 4 & 16 & 2,53 \\
\hline & & 46 & 138 & (Baik) \\
\hline & & 34 & 68 & \\
\hline & & 6 & 6 & \\
\hline \multirow{4}{*}{5} & \multirow{4}{*}{ Kondisi Halte } & 7 & 28 & 2,81 \\
\hline & & 60 & 180 & (Baik) \\
\hline & & 22 & 44 & \\
\hline & & 1 & 1 & \\
\hline \multirow{4}{*}{6} & \multirow{4}{*}{ Kondisi Bangku } & 26 & 104 & 3,1 \\
\hline & & 48 & 144 & (Sangat \\
\hline & & 16 & 32 & Baik) \\
\hline & & 0 & 0 & \\
\hline \multirow{4}{*}{7} & \multirow{4}{*}{$\begin{array}{l}\text { Kondisi Lampu } \\
\text { Penerangan }\end{array}$} & 26 & 104 & 3,07 \\
\hline & & 45 & 135 & (Sangat \\
\hline & & 19 & 38 & Baik) \\
\hline & & 0 & 0 & \\
\hline \multirow{4}{*}{8} & \multirow{4}{*}{ Kondisi Bollard } & 12 & 48 & 2,82 \\
\hline & & 51 & 153 & (Baik) \\
\hline & & 26 & 52 & \\
\hline & & 1 & 1 & \\
\hline \multirow{4}{*}{9} & \multirow{4}{*}{$\begin{array}{l}\text { Kondisi } \\
\text { Tempat } \\
\text { Sampah }\end{array}$} & 6 & 24 & 2,51 \\
\hline & & 41 & 123 & (Baik) \\
\hline & & 36 & 72 & \\
\hline & & 7 & 7 & \\
\hline \multirow{4}{*}{10} & & 12 & 48 & 2,63 \\
\hline & Kondisi Sign / & 56 & 168 & (Baik) \\
\hline & Penanda & 11 & 22 & \\
\hline & & 1 & 1 & \\
\hline & & 13 & 52 & 2,85 \\
\hline 11 & Penataan & 52 & 156 & (Baik) \\
\hline 11 & Lansekap & 24 & 48 & \\
\hline & & 1 & 1 & \\
\hline & & 14 & 56 & 2,87 \\
\hline 12 & Penempatan & 52 & 156 & (Baik) \\
\hline 12 & Furniture & 23 & 46 & \\
\hline & & 1 & 1 & \\
\hline & & 25 & 100 & 3,13 \\
\hline 13 & Estetika Jalur & 52 & 156 & (Sngat \\
\hline 10 & Pedestrian & 13 & 26 & Baik) \\
\hline & & 0 & 0 & \\
\hline & AL & & & 2,59 \\
\hline & AL & & & (Baik) \\
\hline
\end{tabular}

Dari perhitungan skor data persepsi pengguna tentang kondisi Jalur Pedestrian dan Street Furniture di Malioboro mendapatkan perolehan total 2.59 (baik). Nilai terkecil didapat dari kelancaran sirkulasi dengan skor 2.41 (baik) dan poin tertinggi diperoleh dari estetika jalur pedestrian dengan skor 3.13 (sangat baik). 
Setelah didapat data persepsi pengguna tentang kondisi jalur pedestrian dan street furniture, lalu pengujian sampel dilanjutkan dengan melakukan penilaian persepsi tentang pendapat keseluruhan pengguna terhadap jalur pedestrian dan street furniture di Malioboro, apakah sudah memenuhi standar kenyamanan ruang public ataukah belum. Hasil penilaian persepsi seperti dalam gambar 7 .

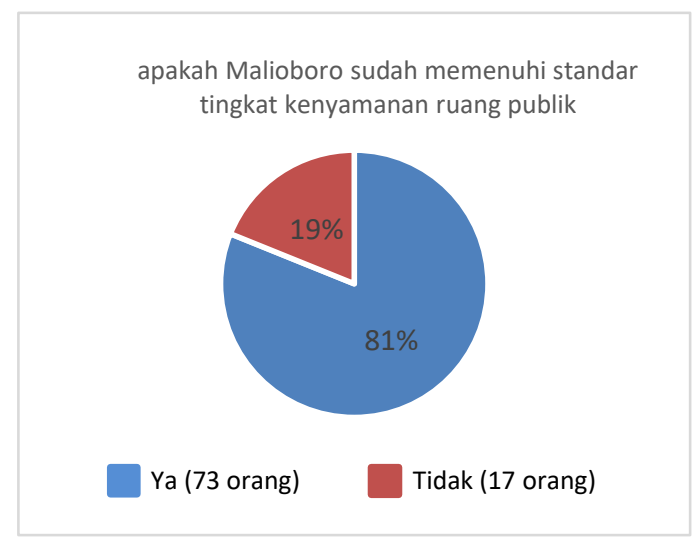

Gambar 7. Persepsi tentang tingkat kenyamanan ruang publik

Gambar 7 menunjukkan bahwa $81 \%$ orang atau 73 orang berpendapat bahwa jalur pedestrian Jalan Mailoboro sudah memenuhi standar tingkat kenyamanan ruang publik, dan 19\% lainnya atau 17 orang belum memenuhi standar tingkat kenyamanan ruang publik.

Dari hasil data di atas menyatakan bahwa Jalan Malioboro sudah memenuhi kriteria nyaman bagi para pengguna yang disesuaikan dengan kondisi fisik dari jalur pedestrian dan street furniture yang ada. Sehingga dapat dikatakan bahwa kondisi dari jalur pedestrian dan street furniture mempengaruhi kenyamanan ruang publik.

Maulani (2010) meneliti tentang penataan jalur pejalan kaki pada koridor jalan berdasarkan persepsi dan preferensi pengunjung pada tahun 2008. Hasil penelitian menyatakan bahwa masih terdapat kekurangan beberapa fasilitas umum dan kondisi jalur pedestrian yang masih kurang memenuhi standar. Seiring dengan perkembangan waktu, saat ini Jalan Malioboro sudah memenuhi standar kenyamanan ruang publik, berdasarkan penelitian yang menghasilkan nilai 2,59 (Baik) atau $81 \%$ dari 90 responden menyatakan sudah nyaman.

Hal ini menunjukkan bahwa dahulu pada tahun 2008 Malioboro belum memenuhi standar kenyamanan ruang publik namun sekarang sudah meningkat kualitasnya dalam memenuhi kenyamanan ruang publik bagi pengguna.

\section{KESIMPULAN}

Penelitian ini menyimpulkan bahwa $81 \%$ pengguna menyatakan sudah memenuhi kenyamanan ruang public, baik jalur pedestrian maupun street furniture. Tingkat kondisi jalur pedestrian dan street furniture di jalur pedestrian Jalan Malioboro dalam keadaan baik dengan nilai rata-rata 2.59 dengan nilai tertinggi sangat baik dari aspek estetika (3.13) dan nilai terendah dari aspek kelancaran sirkulasi (2.41).

Hasil penelitian ini menggarisbawahi perlunya kerjasama pemerintah dan masyarakat dalam memperhatikan dan merawat kondisi jalur pedestrian dan street furniture yang sudah memenuhi standar kenyamanan pengguna.

\section{DAFTAR PUSTAKA}

Dines, C. W., \& Harris. (1988). Time Saver Standar for Landscape Architecture:Design and Construction Data. New York: Mc Graw-Hill Book Co.

Iswanto,2006. Dalam Pengaruh Elemen-elemen Pelengkap Jalur Pedestrian terhadap Kenyamanan Pejalan Kaki.

Maulani,L.,2010. Fungsi dan Peran Jalur Pedestrian Bagi Pejalan Kaki. NALARs, volume 9 no 2 Juli 2010

Planologi_uir_2011. (2012, maret 14). Pengertian Pedestrian. Diambil kembali dari planologiuir2011:

http://planologiuir2011.blogspot.com/2012/03/ pengertian-pedestrian.html

Rapoport \& Mouden, Anne. (1987). Public Streets for Public Use. New York: Van Nostrand Company 